that of the impure passion of remorse he never breathed a syllable. Only upon some return of our own thoughts were we reminded who it was to whom we disembosomed : a man by his own fault ruined ; shut out of the garden of his gifts ; awaiting the deliverer. He had held the inquest, and passed sentence, Mint, menc, "Weighed, found wanting," but he did not rail at circumstance ; no word of self-accusing passed his lips. And then something took us by the throat; and to see him there, so gentle, patient, brave and pious, oppressed but not cast down, sorrow was so swallowed up in admiration that we could not dare to pity him.' You feel the nobility of that. ${ }^{2}$

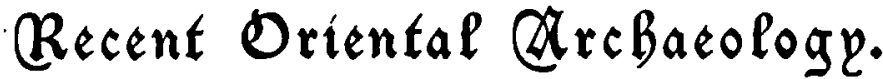

By the Rev. A. H. Sayce, D.Litt. D.D., Ll.D., Professor of Assyriology, Oxford.

ONE of the most important books that have appeared for some time past on ancient Babylonian theology is Dr. Langdon's Babylonian Liturgies (Geuthner, Paris, I 9 I3). The larger part of the volume is addressed to Assyriologists only, and consists of facsimiles of Sumerian religious texts with transliterations and translations. But this part of the volume is prefaced by a long introduction on early Babylonian liturgiology which will appeal to a much wider circle of readers. A considerable portion of the matter contained in it is new and throws a welcome light on the religious services and ritual of the Babylonians.

'Liturgical services,' says Dr. Langdon, 'originated among the Sumerians' and were accompanied by music. They were simple at the beginning, the chief instruments of music being the lyre, the drum and the tambourine, to which the flute was subsequently added. The official liturgist was called a kalit, who was assisted by a professional singer or nîru, who, it may be observed, was not necessarily attached to a temple. Indeed, among these professional singers we find confectioners, gardeners, and the like, and many of them were women. Dr. Langdon would identify naru, 'singer,' with nâm, Heb. na'ar, 'youth,' on the ground that the latter originally signified one who spoke with the shrill voice of boyhood. Songs to the flute he thinks were used in processions, called kidudu in Sumerian, a word which was afterwards adopted by Semitic Babylonian, while hymns to the lyre (or drum), termed kisub, were attended by 'bowings, prostrations, and swaying.'

'In kalii he sees the name of the 'psalmist.' That the word came to represent the psalmist is slear, but I should myself identify its Sumerian prototype with another common word which means 'servant' or 'minister,' the kalí being the Levite of the Babylonian sanctuary. He was at all events distinguished from the consecrated priests, whether high-priests (enu and sangu) or 'prophetical diviners' (asipu), just as the Levites were distinguished from the priests of the Jewish temple. Like the Levites they gradually acquired a footing of equality with the priests, and formed liturgical colleges which kept the temple ritual jealously in their own hands.

Dr. Langdon enumerates and examines the various other names given to the temple servants and explains the functions belonging to them. In fact, nothing connected with the Sumerian ritual seems to have escaped his notice, and even the curious interludes in certain litanies in which a single line is ruled off from the preceding and following intercessions receives from him a probable explanation. He compares it very aptly with the comments of the chorus in a Greek play.

As time went on the ritual naturally developed and became more intricate. While odes and lyrics were dropped, older psalms and similar compositions were combined into litanies of considerable length, and wind and string instruments were employed together. The later and more elaborate ritual can be traced back to the age of the dynasty of Isin, and first takes permanent shape in the epoch of Khammurabi. A comparison of its character and development in the Semitic period with the Mosaic ritual cannot fail to be instructive to students of the Old Testament.

That indefatigable worker, Professor Clay, has given us two new volumes during the past winter, Personal Names from Cuneiform Inscriptions of the Cassite Period (New Haven: Yale University Press, I 12 ), and Babylonian Records in the Library of 
J. Pierpont Morgan (New York, 1912). The last volume is privately printed at the expense of the late Mr. Pierpont Morgan, whose services to archæology will be deplored by none more than by the Assyriologist. The tablets copied by Professor Clay belong to the Neo-Babylonian period (with the exception of two which are dated in the reign of Nebuchadrezzar 1.), beginning with Nabu-sumiskun, the predecessor of Nabonassar, and ending with Antiochus III. ( 187 r.c.). One of those dated in the reign of Antiochus shows that the worship of Anu still predominated at Erech as late as r9o B.c. Most, if not all, of the tablets must have come from Erech, and the number of foreign names in them is interesting as indicating that the proportion of foreigners in the service of the temple in the later Babylonian age was greater than that of the native Babylonians. Among the names is Bakhianu, the name of a Hittite prince in the time of Assur-nazir-pal.

In compiling the list of personal names in the Cassite period, Professor Clay has performed a laborious but very useful piece of work. His classification of them is excellent, and the book will be indispensable to all future workers in the same field. Additions can doubtless be made to it even now, and corrections will be introduced here and there with the advance of knowledge. But the work must always remain 2 sort of bed-rock for the study of the early nomenclature of Western Asia.

In the Procedings of the Society of Biblical Archæology for last February, Mr. L. W. King has an interesting article on some inscriptions of Sennacherib engraved upon the rocks of Jebel Judi, the existence of which was first noted by Layard. Jebel Judi-Judi Dagh in Turkishrises on the north-eastern bank of the Tigris, not far from Shakh, and in a line due south of Lake Van. Mr. King, followed by Mr. R. C. Thompson, found and copied six of them, and though they are all more or less in a mutilated condition a comparison of the six inscriptions has enabled him to put together a fairly complete text. The inscriptions prove to be a record of Sennacherib's campaign against the cities of Mount Nibur, which thus turns out to be the modern Jebel Judi, and not a range of mountains further to the west as has hitherto been supposed. As Mount Nibur lay on the eastern frontier of Kummukh, or Comagene, the geographical position of that kingdom also must be shifted somewhat to the east. Jebel Judi was the mountain on the summit of which, accordto 'a widespread Eastern tradition,' the ark rested, and the antiquity of the tradition is attested by the early Babylonian map of the world which I published in The Expository Times (November I g06).

Another important Assyriological work which has appeared this winter is M. Thureau-Dangin's Relation de la Huitiome Campagne de Sargon (Geuthner, Paris, I9I3), which is a very brilliant performance. The French Assyriologist has been fortunate enough to come across a tablet containing a letter addressed by Sargon to his god Assur and describing in detail the military operations of the eighth year of his reign. The text has been. corrected and completed in many places by a comparison with the historical inscriptions of the Assyrian king, and the translation accompanying it is a masterpiece.

The eighth year of Sargon's reign was especially important, as it witnessed the capture of the city of Muzazir and the final overthrow of Armenian: supremacy in the north. The new inscription throws a flood of light on the event as well as on the history of Ararat or Armenia and the geography of the country north of Assyria. M. Thureau-Dangin is certainly right in the new arrangement which he proposes for the kings of Van. In Rusas, the opponent of Sargon, he sees. the son of Erimenas, who founded a new dynasty unconnected with that of his predecessor Sarduris. In fact, Sargon states explicitly that while Riar. was the paternal city of Sarduris, Arbu was the city of Rusas.

On the geographical side the gains from the new inscription are great. The land of Khubuskia must lie to the south of Lake Van, and $M$. Thureau-Dangin is certainly justified in identifying the town of Uaiais, which plays so large a part in the correspondence of the Second Assyrian Empire, with the modern Bitlis. As for Muzazir, the Armenian name of which was 'the city of Ardinis,' the Sun-god, the inscriptions of Kelishin and Topzawa had already made it clear that it must have been to the south-west of Lake Urumiya.

The new inscription abounds with rhetorical passages some of which describe the scenery and productions of the countries through which the Assyrian army passed. The account of the spoil obtained after the capture of Muzazir is peculiarly 
nteresting. Among it was a bronze statue of Rusas, which, we are told, represented the Vannic ing in his chariot together with his charioteer ind two chargers, the whole being accompanied sy the inscription: ' With my two horses and my one charioteer my hand has conquered the kinglom of Ararat.' Another article of the spoil was $\checkmark$ golden signet-ring dedicated to Bagbartu, the vife of the supreme god Khaldis. There were Ilso baskets for plants in ivory, ebony, and boxvood, mounted in gold and silver, bronze keys in he shape of crowned goddesses with dogs under heir feet, locks moulded like human hands, the iilver cup of Rusas, besides ten others with golden aandles from the land of Tubal, vestments of blue and scarlet wool from Ararat and Kilkhu, the jewellery of the Vannic deities, silver cups of Assyrian, Armenian, and Kilkhian work, and other precious objects to an almost incalculable amount. There was also a great bronze bowl, holding So measures of water, which 'the kings of Ararat filled with wine when pouring out libations' to their god, as well as a bronze statue of the Vannic king Argistis, with his right hand held out in the act of blessing.

Dr. Pinches has given a resume of the inscription in the recent number of the fournal of the Royal Asiatic Society. $\mathrm{He}$ is there clearly right in reading the name of the city on the seal of Urzana, king of Muzazir, as Uarti ; that must have been the native name of the town which the people of Ararat knew as 'the city of the Sun-god.'

\section{In the $\mathfrak{g}$ tudp.}

\section{Miner Germons and Expositions.}

For the first time we have this month the privilege of reviewing a volume of sermons by a woman. IVe wish it were a better volume. IVe wish it were more intelligible, that it would hang together better, that it would say something and get on. But there is just one idea in every sermon. Round that idea all gathers-quotations from Scripture, quotations from Mrs. Eddy, endless words and combinations of words. This is the idea-almost any paragraph will express it.

'Science reverses the testimony of the material senses and declares that man is spiritual, not material. In spiritual thought all is harmony. "Chaos and old night," discord and disease, sorrow and death, are produced by the carnal mind, belief of life in matter. Let us refuse longer to believe the suggestions of mortal mind. God reigns and there is none beside Him. All is Life. All is Love and Truth. Adam is a myth. In the Adam-thought all die. In the Christ-mind all are made alive.'

The book contains much more than sermons. Mrs. Augusta E. Stetson, C.S.D., minister of the First Church of Christ, Scientist, New York City, has been a voluminous letter-writer, and many of her letters are quoted in this volume. Are they more intelligible than the sermons? Not a bit.
What comfort, warning, or other meaning her 'beloved Students' got out of them, it is impossible to conceive. 'They make a tremendous claim. They say, 'We are the sheep of Love's pasture. We love divinely. God is our life, therefore we are forever with the Father-Mother God. We reflect omnipotence and omnipresence. Truth demonstrates Her power and presence to us, Her ideas.' But what can that do for 'students' unless to show them to the world 'vainly puffed up with their fleshly mind '?

It is altogether an amazing book. It contains I 200 pages, which the publishers have kept within compass by using India paper. It is illustrated at much expense.

Among the rest of the portraits there is one of Mrs. Eddy 'in a setting of forty diamonds.' The whole title is.Reminiscences, Sermons, and Correspondence, proving Adherence to the Principle of Christian Science as tausht by Mary Baker Eddy (Putnams; 2 Is. net).

Fear not, little flock; for it is your Father's good pleasure to give you the kingdom ( $\mathrm{Lk} \mathrm{r}_{2}{ }^{32}$ ). Here is a fine mixture of metaphors. Three worlds, says Dr. A. C. Dixon, are comprehended in one verse-the world of the shepherd, the world of the Father, and the world of the King. And just because of the mixture of metaphors he chooses 